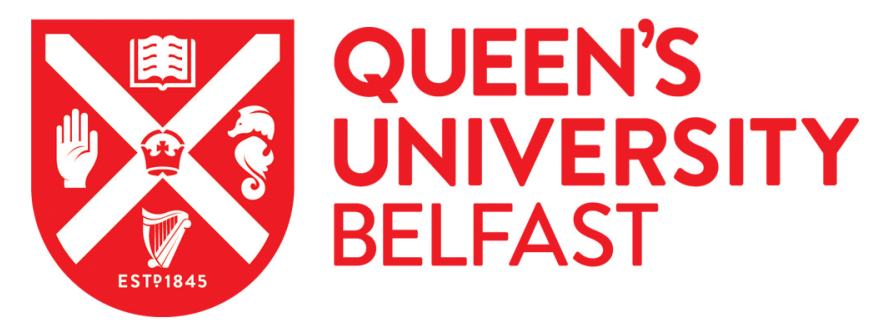

\title{
After the Male Breadwinner Model? Childcare Services and the Division of Labor in European Countries
}

Ciccia, R., \& Bleijenbergh, I. (2014). After the Male Breadwinner Model? Childcare Services and the Division of Labor in European Countries. Social Politics, 21(1), 50-79. https://doi.org/10.1093/sp/jxu002

\section{Published in:}

Social Politics

\section{Document Version:}

Peer reviewed version

Queen's University Belfast - Research Portal:

Link to publication record in Queen's University Belfast Research Portal

\section{Publisher rights}

This is a pre-copyedited, author-produced PDF of an article accepted for publication in Social Politics following peer review. The version of record, After the Male Breadwinner Model? Childcare Services and the Division of Labor in European Countries, Rossella Ciccia, Ingle Bleijenbergh, Soc Pol (Spring 2014) 21 (1): 50-79. doi: 10.1093/sp/jxu002. is available online at: http://sp.oxfordjournals.org/content/21/1/50

\section{General rights}

Copyright for the publications made accessible via the Queen's University Belfast Research Portal is retained by the author(s) and / or other copyright owners and it is a condition of accessing these publications that users recognise and abide by the legal requirements associated with these rights.

Take down policy

The Research Portal is Queen's institutional repository that provides access to Queen's research output. Every effort has been made to ensure that content in the Research Portal does not infringe any person's rights, or applicable UK laws. If you discover content in the Research Portal that you believe breaches copyright or violates any law, please contact openaccess@qub.ac.uk. 


\title{
After the Male Breadwinner Model? Childcare Services and the Division of Labour in European countries*
}

\author{
Rossella Ciccia \\ Department of Sociology/ NIRSA - National University of Ireland Maynooth \\ Inge Bleijenbergh \\ Institute for Management Research -Radboud University Nijmegen
}

*A revised version of this paper has been accepted for publication in Social Politics: International Studies in Gender, State \& Society.

\begin{abstract}
Fundamental reforms in childcare services appear to have eroded traditional support to the male breadwinner model across European states. There has been a strong debate about the direction of these changes, and the ways in which childcare services can alter the division of labour and promote gender equality. This paper deals with these issues by using fuzzy set ideal type analysis to assess the conformity of childcare service provisions in European economies to Fraser's four ideal typical models: male breadwinner, caregiver parity, universal breadwinner and universal caregiver. We find that there is resilience of traditional gender roles in the majority of European countries, while there are different variants of the universal breadwinner shaping different forms of childcare policies. The more equalitarian universal caregiver model maintains its utopian character.
\end{abstract}




\section{Introduction}

The analysis of the implicit gender assumptions underlying welfare states has been the object of a vast body of scholarly research (Crompton 1999; Gornick and Meyers 2003; Jenson 1997; Lewis 1992; Mahon 2002; O’Connor 1993; Sainsbury 1996;). This early scholarship has demonstrated the dominance of normative assumptions in Western European welfare states concerning the existence of a male breadwinner and female homemaker model. Even though this model was never dominant in its pure form (Crompton 1999), it worked very much at the level of prescription of appropriate behaviours for men and women, and served to underpin social policies assuming women's dependence on a breadwinner's wage (Lewis 2001).

European welfare states have adopted significant reforms in recent decades, which might have fostered shifts in policy assumptions about gender roles. Childcare services have become a salient political issue. On the one hand, they are considered essential to raise maternal employment in the context of social policies increasing requiring that all individuals are selfsupporting, active members of labour markets (Lewis 2001, Bleijenbergh et al., 2006). On the other hand, the emergence of a social investment perspective highlights childcare services as central for future human capital accumulation (Jenson 2009). As a result, public provision of childcare services has increased in many countries, in spite of retrenchment tendencies in other social policy areas; though there remain considerable differences across European societies with regard to their development (Morgan 2013).

Many scholars suggested that these changes highlight a shift from the male breadwinner toward a universal breadwinner (or adult worker) model, aimed at promoting men's and women's equal participation in the labour market. (Crompton 1999; Fleckenstein, 2011; Leira and Saraceno 2008; Lewis and Giullari 2005; Orloff 2006). However, others have contended that in many countries childcare policies continue to rely considerably on maternal care and/or to 
promote at best a one-and-a-half breadwinner model (Daly 2011; Lewis et al. 2008; Morgan 2008; Plantenga 2002; Birgit Pfau-Effinger 2005). As argued by feminist scholars, policies that increase employment opportunities for women without affecting the balance of unpaid work in the home can at best yield a partial form of gender equality. The universal caregiver (Fraser 1994) or dual-earner/dual-caregiver model (Crompton 1999; Gornick and Meyers 2009) represents an alternative vision of a gender equalitarian society which values equally paid and unpaid work, and supports the redistribution of unpaid labour between a wide range of actors (men, women, families, the state and the market). This model might not yet exist empirically, although Scandinavian countries are generally considered to provide the most fully developed examples (Gornick and Meyers, 2009).

In spite of the existence of contrasting views about the direction of current changes and intense debates on the implications of childcare services for the gender division of labour, few empirical studies have systematically analyzed the empirical validity of such statements by incorporating a large set of countries (Korpi 2000; Korpi et al. 2013). Comparative research has predominantly focused on the effect of childcare services in terms of defamilialisation, that is the degree to which policies promote the movement of care work traditionally performed inside the home to the formal, paid sector (Bambra 2007; Chau and Yu 2012; Hantrais 2004; Javornik forthcoming; Saraceno and Keck 2010; Rauch 2007; Szelewa and Polakowski 2008). However, defamilialisation as a concept is affected by many ambiguities, since it does not provide recognition for individuals' right to time for care (Knijn and Kremer 1997), nor does it confront the issues of the unequal gender division of labour and men's role in caregiving (Saxonberg 2012). As such, defamilialisation is insufficient to assess gender equality in childcare policy.

This paper aims to fill this gap in comparative research by conceptualising and measuring variations in normative assumptions about gender roles in childcare service provisions across European states. The challenge is to think about the ways in which childcare services can alter the division of labour in a direction that is compatible with a universal caregiver ideal. In this sense, it contributes to the debate on the ways in which such an ideal is 
translated in actual policy measures aimed at advancing gender equality (Gornick and Meyers 2009; Morgan 2008), and which countries promote such configurations. Moreover, it deals with the empirical question of national differences in the ways in which the male breadwinner model has been modified and the existence of sub-variants within alternative models. Finally, this study considers a large number of European countries, including Central and Eastern European, in order to assess similarities and differences across the region.

In contrast to previous research investigating overall welfare regimes, this paper adopts a programme approach (Hinrichs, 2000) focusing on the institutional characteristics of childcare service provision. We use fuzzy set ideal type analysis (FSITA) to assess the extent to which childcare services in thirty European states promote different models of division of labour (Fraser, 1994). This enables us to evaluate the implications of different policy configurations regarding to the division of paid and unpaid work and the role of different actors (men, women, families, states, markets). The results of this analysis are then used to advance the theoretical debate about what constitutes the optimal (most equitable) balance of paid and unpaid work for men and women, and the role that should be played by governments (Mahon 2002).

\section{Theoretical discussion}

\section{Welfare state research and the gender division of labour}

A substantial amount of feminist scholarship shows that normative assumptions about gender roles and the social organization of care lie at the heart of welfare states. These not only constraint parental choices and opportunities but also determine cultural ideals about the proper way to perform childcare and the ways in which parents should share this task (Hobson 2011; Kremer 2007; Pfau-Effinger 1998). At their origin, all modern welfare states adhered to the male breadwinner ideal, although research also demonstrates the existence of national differences in the extent to which social policies embodied such a model (Lewis 1992; O'Connor 1993; Sainsbury 1996). 
A number of scholars have recently advanced the idea that many European welfare states have significantly departed from actively supporting the male breadwinner model (Crompton 1999; Leira and Saraceno 2008; Lewis 2001; Lewis and Giullari 2005; Orloff 2006). This change is interpreted as the response to a number of larger transformations concerning both families (increased instability, declining fertility) and labour markets (growing female employment, scarcity of breadwinner wages), which have also led to the financial instability of welfare states. Lewis (2001) characterizes this shift as a movement toward what she defines an adult-worker model, implying a new set of assumptions about women's contribution to work and family. Similarly, Orloff (2006) speaks of 'farewells to maternalism' in gender policy logics. Despite using different labels, these authors share a common view of the empirical features of the policy template involved (Daly, 2011). First, social policies have shifted from supporting women as full-time caregivers to promoting and requiring some form of employment for all (activation). Secondly, the link between access to social security rights and individuals' relation to the labour market has been tightened (individualisation). Thirdly, social policies increasingly promote the movement of care work traditionally performed inside the home to the formal, paid sector in order to free mothers (as well as fathers) for full-time continuous employment (defamilialisation and commodification of care).

Although authors have been careful to highlight the positive implications of the universal breadwinner model in terms of increased autonomy and choice for women, they also demonstrate that such a model is flawed both as a normative ideal and analytical tool to investigate variation in policies' assumptions. First, this model limits gender equality to the labour market and neglects the persistence of unbalances in the gender division of unpaid work (Ciccia and Verloo 2012). Within the universal breadwinner model, parental care remains substantially unvalued, an obstacle to individuals' full participation in employment. Accordingly, the aim is not to raise men's participation in unpaid labour but rather to diminish that of women. Nonetheless, there is always a portion of time and a number of activities that cannot be covered by formal providers (either the state or the market) (Tronto, 1993), 'for neither the 
state not any other social institutions have the resources to take care of a large number of children around the clock' (Anttonen 2005). By leaving unproblematised cultural norms that assign primary responsibility for unpaid work to women, the universal breadwinner model can have the undesired consequence of burdening women with a double load owing to the conflicting expectations attached to being a full-time worker and good caregiver.

Secondly, the universal breadwinner model is underspecified as a comparative approach (Daly, 2011). Indeed, it was developed to describe a particular direction of change in European social policies, and not as part of a larger framework intended for the analysis of cross-national deviations from or variations within such a model. A useful starting point to think about subtypes is the work of Rosemary Crompton (1999) and her distinction between dual earner/state carer and dual earner/marketised carer societies. The former facilitates women's full-time employment by providing substitute care in the form of extensive public childcare services, while in the latter a high share of women are employed full-time and families make extensive use of private market care arrangements. Although these models hold similar assumptions regarding the gender division of labour, they bear different consequences for class inequality, given that lower income families can only limitedly access childcare facilities, and especially good quality services, in the absence of public support. Moreover, the market driven version further reinforces gender inequalities because of the low wages paid in care jobs, which are still disproportionally held by women (Gornick and Meyers 2009).

In spite of the great attention given to the emergence of the universal breadwinner model, a number of authors argue that it represents a poor description of reality. Increasing rates of female employment have not eliminated other fundamental disparities in the labour market, particularly concerning working hours. In all European countries, women are more likely than men to work short hours, with female part-time work increasing in many countries (Lewis et al. 2008). In this view, many European states would continue to rely greatly on the informal care provided by women, and favour a one-and-a-half breadwinner model (Lewis 2001; Daly 2011; Morgan 2008; Plantenga 2002; Birgit Pfau-Effinger 2005). This model 
represents a modification rather than a transformation of the male breadwinner model, since it is not associated with substantial changes in gender relations, nor does it address women's lack of full financial autonomy (Crompton 1999). Its most common form is the female part-time caregiver willing to scale back her working hours in order to combine primary responsibility for family care with employment in a part-time job. In this view, there might also be more resilience of male breadwinner norms than usually recognised.

\section{Childcare services beyond regimes and defamilialisation}

This analysis focuses on the institutional characteristics of childcare services because of their salience in current academic and political debates about the reconfiguration of paid work and care responsibilities (Lewis, 2001). Scholars correctly point out that the net effect on the ways in which parents combine paid and unpaid work depends on a wide array of policies (cash transfers, leave facilities, childcare services, working-time regulations, taxation) (Gornick and Meyers, 2003; Saraceno, 2011). Nevertheless, as illustrated by Hinrichs (2000), a 'programme approach' analysing single social policy components might be better suited to answer questions concerning change and stability. Whereas regime approaches focusing on overall policy logics tend to emphasise stable conditions and path dependence, a programme approach emphasises that every social policy component has its specific conditions of development, functioning and perpetuation. Accordingly, if dynamics affecting welfare states in their totality can be ascertained, this should be even more true for their components, since reforms and political decisions typically concern single programmes and only rarely affect the welfare state as a whole (Hinrichs 2000, 354).

A further reason for the adoption of a programme approach derives from the complexity of childcare policies. Welfare states provide early childhood education and care (ECEC) services for a variety of reasons. In some countries they were first introduced with pronatalist aims (France), while in others primarily to reduce children's poverty (United Kingdom), or encourage 
women's employment and reduce gender inequalities in paid and unpaid work (Nordic countries). Given the large and varying set of objectives attached to childcare policies, this field remains characterised by ambiguities and tensions over the treatment of non-parental care, which are reflected in large cross-national differences in the scale, scope and targeting of childcare services. Secondly, there is also great national variation in the nature and number of actors involved in the provision of childcare services. In some countries, childcare services are mainly provided by governments, yet in others by private enterprises or voluntary associations, or various combinations of public and private sources. Alternatively, some countries rely predominantly on childcare supplied by family members, supported by the state to differing degrees and in various ways (Anttonen 2005; Morgan 2005). Given the wide set of dimensions involved in the organisation of childcare, an approach focusing on the single characteristics of childcare services may contribute to make sense of these complexities and their influence on gender roles.

The analysis of childcare services is central in research analysing the division of responsibilities between state, market and families (Javornik forthcoming, Leitner 2003; Rauch 2007;Saraceno and Keck 2010; Szelewa and Polakowski 2008). A popular analytical concept is that of 'defamilialisation' defined as the movement of care work traditionally performed inside the family to the formal, paid sector. Typically, countries are positioned along a continuum from familialistic to defamilialistic, or within different types of familialism according to the role of the state in diminishing or strengthening families' caring responsibilities (Leitner 2003; Saraceno and Keck 2010). However, despite this concept having being fruitfully applied in many social policy analyses, it also presents some limitations. First, the concept is itself ambiguous. If taken literally, one would expect that its goal is to take responsibility for childcare away from parents as soon as possible (Saxonberg, 2012). Nevertheless, the promotion of informal care does not necessarily contradict ideas about gender equality, provided that this is not perceived as a moral claim and that it does not frustrate caregivers' right to make an autonomous choice. Therefore, there is limited recognition within the defamilialisation framework of parental right 
to time for care (Knijn and Kremer, 1997). Most importantly for this analysis, families remain undifferentiated units and the role of men in care remains unproblematised. Accordingly, we are unable to distinguish between generous policies intended to support women's role within the home, from equally generous policies that are also intended to promote men's involvement in caregiving. Both types of policies would be classified as familialistic, despite bearing very different effects on gender relations.

It is more difficult to differentiate between childcare service models in relation to the division of labour than for instance parental leave policies (Saxonberg 2012). In contrast to leave policies that can directly promote a more equal distribution of unpaid work (e.g. through fathers' quotas), formal childcare removes a piece of families' (women's) care load and places it within an institution outside the home. However, it does not intervene in the way in which men and women divide the remaining portion of their care responsibilities. Few studies have investigated the influence of childcare services on the gender division of care work (Crompton 2006; Gregory and Windebank 2000). These analyses demonstrate that contradictory effects are possible. For example, Gregory's and Windebank's study shows that there is less gender equality in domestic work in France than in the UK, despite the fact that French women are more likely to be working full-time. The authors suggest that this might also be the consequence of extensive provision of childcare services in France, which would enable men to fall back on the state when their partners are in employment, while British men are forced into domesticity in order to enable their partners to work. Moreover, childcare services can also indirectly act to reinforce gender inequalities because of the of the prevalence of female workers in care jobs (Gornick and Meyers 2009). Nevertheless, the effects of childcare services on the division of labour are likely to vary from country to country and depend largely on their design (Crompton 2006). 


\section{Childcare services and ideal typical models of division of labour}

Fraser (1994) advanced the idea of a universal caregiver society as a solution to the long-standing feminist debate about whether women's attainment of equality required that women be treated the same as men or rather that women's differences be recognised and provided for. This model has increasingly drawn the attention of feminist scholars (Crompton 1999; Gornick and Meyers 2009; Haas and Hartel 2010; Morgan 2008; Pfau-Effinger 2005), who also identify alternative arrangements to the male breadwinner model. Differences between these models are illustrated below, and concern the extent of men's and women's engagement in paid and care work, carers' financial independence, and the underlying gender (in)equality ideal.

- The male breadwinner model (MB) is based on an ideology of separate gender roles with men working full-time outside the home and women responsible for domestic/reproductive activities. Women depend financially on their husbands' income or on derived entitlements to social benefits based on their status as wives and mothers (unvalued gender difference).

- The caregiver parity model (CGP) maintains traditional gender roles yet values them more equally. Women remain responsible for childcare but states recognise the value of their unpaid work through generous care allowances and other benefits (valued gender difference).

- The universal breadwinner (UB), or adult-worker model (Lewis and Giullari 2005), promotes women's and men's equal engagement in the labour market. In order for women to be fully integrated in employment, childcare must be removed from households and performed by paid workers in formal settings. Care remains fundamentally unvalued in comparison to paid work (market oriented gender sameness). 
- The universal caregiver model (UC) or dual-earner/dual carer (Crompton 1999; Gornick and Meyers 2009) aims at transforming gender roles inside and outside the labour market by promoting men's and women's equal engagement in paid and unpaid work (Fraser 1994). Accordingly, care is a responsibility of both families and other actors (state, employers), with paid work and care considered equally valuable activities. This model also requires major transformations in the workplace since it acknowledges mothers' and fathers' equal right to reduce their working hours to care for children (Gornick and Meyers 2009) (transformative gender sameness).

While Fraser's work deals with philosophical normative ideals, the more recent works also discuss the kind of policies that should be put in place to advance the universal caregiver model. In particular, Gornick and Meyers (2009) have developed a policy blueprint intended to foster the movement towards the universal caregiver model. Mainly inspired by the experience of the Nordic countries (the 'real utopia' of gender equality), this template is based on three set of policies: 1) individual rights of mothers and fathers to generous parental leave periods; 2) working-time regulations that limit full-time work hours and increase the availability and quality of part-time jobs; and 3) high quality, publicly financed, universally accessible childcare services. Therefore, provisions in other policy fields also mould the institutional features of childcare services. For example, with the provision of paid leaves and greater flexibility in working hours, parents will make a limited use of childcare services in the first months after childbirth, and arrange their working schedules to provide substantial amounts of care beyond the first year. The use of day-care services will increase as the child approaches preschool age (3-4 years) (Gornick and Meyers 2009: 25). Indeed, one of the defining characteristic of the universal caregiver (UC) model is the recognition of men's and women's equal right and responsibility to time to care for their children, especially for the very young. It assumes that parents should have realistic opportunities to choose whether they care for their children on their own or rely on substitute forms of care. Therefore, this model configures childcare 
services as widely available but part-time (Gornick and Meyers 2009; Pfau-Effinger 2005). Moreover, since care is conceived as a responsibility of families and public actors, the state offers financial support for childcare, which is also intended to equalise access to high quality care across families with different levels of economic resources (Gornick and Meyers 2009).

Each of the other models of division of labour also promote different ideal typical configuration of childcare policies (table 1). The ideal place for the care of children is at home with their mothers both for the male breadwinner model (MB) and caregiver parity model (CGP). Therefore, childcare places are scarce as is public financial support for services. However, the CGP model differs in one important aspect as it supports mothers through wellpaid leaves intended to strengthen their caring role. The one-and-a-half breadwinner (OHB) model represents a modern variant of the male breadwinner model. This model encourages women to work part-time, but neither promotes their financial autonomy nor relieves them from being chiefly responsible for the care of children and other dependant family members (Crompton 1999). Care remains primarily within the family, and it is mainly women to have to adapt their working schedules to their family duties. Therefore, part-time childcare services represent a feature of this model. Conversely, the universal breadwinner (UB) model actively seeks to shift childcare to the formal sector, and thus day-care facilities are widely available on a full-time basis. Nonetheless, the organisation of care is not among the priorities of governments and the role of public actors vis-à-vis other provides is generally limited. However, a second variant is also possible in which public resources are aimed at supporting parents' use of formal facilities because of the general positive effect of childcare services on maternal employment (Del Boca et al. 2009, Pettit and Hook 2005).

[Table 1]

\section{Data and method}


In this paper, we use fuzzy set ideal type analysis (FSITA) to assess the extent to which childcare services in European countries are organized according to the ideal typical divisions of labour identified in the literature. FSITA is a method for assessing diversity across a limited number of cases, which has its origin in qualitative comparative analysis (QCA) and fuzzy set social sciences as articulated most extensively by Ragin (2000). It has been employed in studies of welfare state change (Kvist 1999; Hudson and Kuhner 2009; Vis 2007), and more limitedly to the comparison of national childcare provisions (Ciccia and Verloo 2012; Szelewa and Polakowski 2008).

In comparison to statistical methods commonly used for classification (indices, z-scores, cluster analysis), FSITA entails a number of advantages for the analysis of childcare services. The complexity of childcare services derives from the fact that many aspects must be considered (availability, opening hours, affordability), while each may assume a different meaning according to the others comprised in the overall policy (Anttonen 2005). For example, part-time childcare services are compatible with different models according to the level of public financial support, which can be low as in the OHB, or high as in the UC model. FSITA overcomes this limitation by viewing those different aspects not as independent variables but rather as elements of configurations that only have meaning in relation to the whole that they form (Kvist 1999). Second, the fuzzy set approach does not allow for compensation effects (Hudson and Kuhner 2010). If a country offers a limited number of childcare places, it cannot compensate for this by offering generous financial contributions. Each aspect within a configuration matters in order to establish a country's membership in a given ideal type. Finally, FSITA also allows for the evaluation of differences in degree of membership. Given that ideal types are rarely encountered in reality, cases will normally show only partial memberships $(<1)$ reflecting their distance/proximity from a given ideal type. In this sense, the fuzzy-set approach is more transparent than other techniques regarding the hybrid nature of some countries' policies (i.e. cases with weak membership). Moreover, by examining these countries' scores in 
the non-membership configurations $(<.50)$, we might be able to detect traces of those other models present in their policies.

FSITA entails four basic steps. First, we must identify theoretically relevant dimensions of the ideal types leading to the construction of a useful property space, i.e. all logically possible combination of the dimensions. The number of possible ideal typical locations is $2^{\mathrm{k}}$, with $\mathrm{K}$ equal to the number of aspects considered. However, not all these combinations need to be theoretically relevant or empirically valid (Vis 2007). The number of dimensions mustn't be too high, to avoid the risk of many empty cells and each case resulting in a different configuration, but should also be sufficient to ensure that they exhaust the core theoretical meaning of the ideal types, and that each type is described by a distinct combination of conditions (i.e. mutually exclusive).

Secondly, each of these dimensions is defined as a set in which cases can have a degree of membership. Once the dimensions are translated into empirical indicators, the researcher must establish qualitative anchors in order to transform empirical values into 0 to 1 fuzzy scores (calibration). Accordingly, three breakpoints are defined for each dimension: full membership (1), no membership (0) and the crossover point (.50), representing the point where a case begins to move from being more out to being more in the set. This operation rests on theoretical and substantive knowledge of the phenomena investigated. In this sense, FSITA forces the researcher to reconsider the data in relation to external conceptual standards, and is not content with using averages and standard deviations that depend on the characteristics of the cases investigated ${ }^{\mathrm{ii}}$.

The next step is the calculation of each case's membership score in the relevant configurations. Two principles of fuzzy theory are particularly useful. The minimum principle states that the conformity of a case to an ideal typical location is given by the minimum score in the set involved, since a case scoring low on dimension $A$ and high on $B$, can hardly be conceived as belonging to the ideal type $A^{*} B$ (where ${ }^{*}=$ and). The second principle is logical negation. To 
the extent to which a case is not fully in a certain set, it is partly in the set defined by its absence. For instance, if a case has a membership of .60 in set $A$, its corresponding score in the set $\sim A$ (where $\sim=$ not) will be .40 . Each case can only have membership (fuzzy score $>.50$ and $\leq 1$ ) in one configuration.

\section{Defining childcare service ideal types}

The organisation of childcare services differs greatly from country to country (Saraceno 2011; Szelewa and Polakowski 2008). In this paper, we consider three dimensions: 1) childcare service coverage $(\mathrm{S}, \mathrm{C})$; 2) formal childcare time $(\mathrm{H})$; and 3) public financial support for childcare services (M). The choice of these dimensions is derived from the theoretical debate about the key features of the organization of childcare services within different ideal typical gender divisions of labour (Crompton 1999; Gornick and Meyers 2009; Lewis, 2001; Morgan 2008).

The first dimension measures the extent to which primary responsibility for childcare is moved from the home to formal settings such as centre-based childcare facilities run by public or private actors. It does not distinguish between private or public facilities as it describes differences in the degree to which childcare is outsourced to any formal institutions. However, in order to distinguish the male breadwinner from the caregiver parity model, we need to consider that the need for childcare services is also shaped in combination with leave policies (Gornick and Meyers 2009). Accordingly, this dimension considers both: 1) the extent to which childcare services in combination with parental leave cover the first years of children's lives (S); and the degree to which this childcare mix is oriented towards childcare services (C).

The second dimension concerns the schedule of childcare services and highlights that their characteristics are also shaped in interaction with working time policies. Limited hours of childcare are an essential feature of the one-and-a-half breadwinner model. According to Daly (2011), this model might be predominant today, as childcare services are organized in many 
countries in such a way as to complement rather than substitute family care. At the same time, the recognition of parents' right to reduce their working hours to care directly for their children and use part-time childcare services for the remaining portion of time is also crucial within the universal caregiver model.

The third dimension is specifically intended to distinguish the role of public from market actors. Public financial support is necessary to guarantee equal access to good quality childcare services across families with different socio-economic conditions, and decent wages and employment conditions of childcare workers (Mahon, 2002). Moreover, public expenditure on childcare sends important signals about its value for society (Gornick and Meyers 2009). All such conditions represent key features of the universal caregiver model.

The combination of these dimensions yields sixteen possible configurations, eight of which correspond to the ideal types described in the third section (table 2). More than one configuration describes the universal breadwinner model. This model neither values nor supports family care, and parents receive limited financial assistance concerning the cost of childcare (unsupported universal breadwinner). However, governments may also decide to offer financial support owing to the general positive effect of childcare services on maternal employment (supported universal breadwinner) (Del Boca et al. 2009, Pettit and Hook 2005).

Finally, two combinations describe the male breadwinner and caregiver parity models. The male breadwinner model provides scarce childcare services. However, hours of childcare can be either low $(\sim \mathrm{H})$ or high $(\mathrm{H})$ since the paucity of available services already limits options for childcare outside the home. Within the caregiver parity model is the level of financial support that can be either low $(\sim \mathrm{M})$ or high (M) according to the focus on children's well-being and the quality of related services. Nevertheless, these two combinations highlight the same configuration because they adhere to similarly traditional norms on the gender division of labour, and only differ regarding the level of public investment in children. In this sense, the more generous model comes closer to some version of the social investment perspective (Jenson 2009). 
[Table 2]

\section{Dimensions of comparison}

This section discusses in detail the dimensions defining the ideal types, their operationalization and calibration (table 3)

[Table 3]

Childcare service coverage: The first dimension describes the extent to which the care of very young children (under-threes) is outsourced to institutions others than the family. We use two indicators to measure this dimension. The childcare coverage rate is one of the most commonly used indicators of formal childcare ${ }^{\mathrm{iii}}$, and it represents the number of children cared for in public or private facilities for at least one hour as proportion of all children of the same age group. Childcare coverage rates for children 3-6 are systematically higher than for children under-three (respectively $76.9 \%$ and $23.9 \%$ on average in $2005-2009$ ), and with few exceptions (Poland, Lithuania, Bulgaria, Greece, Romania, Czech Republic) above 70 per cent. Nevertheless, there is a close relationship between coverage rates for children $0-2$ and 3-6 years old ( $r=0.7)$, demonstrating that countries tend to follow the same pattern of provision for both age groups (Saraceno 2011). The correlation is even stronger (0.9) if we consider provision in terms of weekly hours. Given that the largest and most persistent cross-country variations are to be found within the youngest segment (Saraceno 2011), this dimension focuses on services for children under-three.

Childcare coverage rates refer to the usage of formal childcare, and are generally interpreted as indicators of formal childcare supply, since this is lower than demand in most countries (Plantenga et al. 2008). Nevertheless, they relate to uptakes, and are not easily converted to common standards, given that each country has its own constellation of care 
arrangements, comprising day-care centres, preschool education programmes, and leave facilities (Javornik forthcoming, Saxonberg 2012). In particular, we could be drawn to erroneous conclusions about childcare availability because parents use less childcare services than it is available given the existence of provisions in other policy areas such as parental leave $^{\text {iv }}$. In Sweden, for example, the average coverage rate 2005-2009 is 51.2 , in spite of extensive childcare facilities and the right of children under-three to a place in municipal childcare. This low coverage rate reflects not shortage of services but the provision of well-paid parental leave (69 weeks), intended to enforce the Nordic ideal of children's first year with their parents (Eydal and Rostgaard 2011). In order to correct for this, Plantenga et al. (2008) develop an indicator of effective childcare coverage that considers the ways in which cross-national variation in coverage rates are also shaped by the existence of very different leave systems. This index varies between zero (no support) and 156 weeks (full support), and indicates for which part of the period between the birth of a child and its third birthday, parents receive supports either in the form of services or leave entitlements. Accordingly, taking into account the effect of leave entitlements, the Swedish effective coverage rate corresponds to 91.3 weeks, approximately 60 per cent of the $0-2$ period. In none of the countries analysed the available support covers the whole of a child's first three years.

Effective childcare coverage: Full-time equivalent (FTE) ${ }^{\vee}$ parental leave/156 + coverage rate $0-2^{\text {vi }}$

Two countries can have very similar effective coverage rates, but differ considerably with regard to the mix of instruments used. Given our aim to assess the extent to which responsibility for childcare is shifted to the formal sector, we use the ratio between the childcare coverage and effective coverage rate to measure the portion of this childcare mix represented by childcare services. This index equals 100 when childcare services represent the whole policy mix, and zero when they are completely absent.

Childcare mix: childcare coverage 0-2/effective childcare coverage $0-2 * 100$ 
Figure 1 reports European countries' scores on both indexes. Overall, a large degree of variation is observable across countries in level of coverage, orientation towards childcare services and the ways in which these two aspects are combined. In the first quadrant, we find those countries (e.g. Denmark, Sweden) with extensive childcare provisions prevalently composed by services; in those (e.g. Lithuania, Hungary) located in the second quadrant provisions are also extensive but consists mostly of leave facilities; parents receive very limited help with childcare in countries in the third (e.g. Poland, Greece) and fourth (UK, France) quadrants, but childcare services represent the greatest part of the policy mix only in the latter group.

Calibration: For the effective childcare coverage, the first threshold (fully out) is set at 31 weeks representing a situation of very limited coverage ( $20 \%$ of a child's first three years). The second threshold (fully in) is set at 125 weeks corresponding to extensive childcare coverage ( $80 \%$ of this period), while the crossover point at 52 weeks reflects a moderate level of assistance (33\% of this period) (Saraceno 2011). For the childcare mix index, the minimum threshold is set at $20 \%$ corresponding to a situation of limited availability of childcare services. The maximum threshold is set at $80 \%$ and not at the maximum value $(100 \%)$ since, while it is important that families receive childcare support during the first years of the child, policies should also recognize parental right to time to care for their children, for instance in the form of

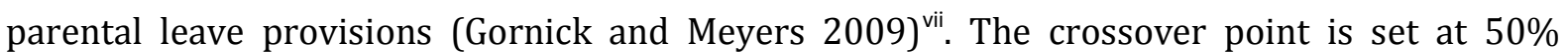
(overall balance in the mix of instruments).

[Figure 1] 
Formal childcare time: Hours of childcare services have important effects on the extent to which parents' duty and right to perform childcare is enforced. Accordingly, we look at the average number of weekly hours of formal childcare for children under-three viii. Figure 2 shows that childcare services are provided for 30 or more hours in half of the countries analysed, while four countries (Czech Republic, the Netherlands, Switzerland, UK) stand out for their very short weekly hours (less than 20). Calibration: the first threshold (fully in) is set at 30 hours, given that full-time formal childcare is assumed to be at least 30 weekly hours according to international conventions (European Commission 2004; OECD 2001). The second threshold (fully out) is at 10 weekly hours (few hours of childcare per day), while the crossover point is set at 20 hours corresponding to the average working hours of a part-time worker in the EU 27 (Eurostat 2010).

[Figure 2]

Public financial support: Levels of expenditure crucially depend on what is considered the most appropriate form of care for children. If government's preferences are for home-based care, the financial burden of services will probably fall mostly on families. Conversely, if governments aim at universally accessible childcare outside the home, public resources will cover a higher share of total costs. Furthermore, public expenditure has important implications for the affordability and quality of the services provided. We can reasonably expect that higher levels of expenditure correspond to parents' smaller contributions and higher quality services (e.g. in terms of child-staff ratio, care workers' qualifications and salaries) (Myers 2000).

While most European countries provide some care or preschool for the majority of children 3-6 years and cross-national variations are not as significant as for the under-threes, there is considerable diversity in public financing of such services (Saraceno 2011; Morgan 2005). Therefore, we need to incorporate expenditures for children below compulsory school age in our measure of public financial support in order to account for such differences. 
Direct provision through public childcare services and pre-school programmes constitutes the bulk of public childcare expenditure in most countries. Therefore, the first component of our measure of public financial support comprises direct social expenditure on childcare services. Governments can also make use of other financing mechanisms, including subsidies towards private care, incentives for employer contributions and tax relief (Morgan 2005). Unfortunately, comparative data on these aspects is largely unavailable ${ }^{\mathrm{ix}}$. The consequences of this are diminished by the fact that these mechanisms represent greater privatisation compared to direct provision, i.e. reliance on private family or market sectors to cover childcare costs or to provide childcare services (Gornick and Meyers 2003).

A first complication in comparing cross-country levels of financial support stems from the fact that the dividing line between social care and educational services is not always clear (Randall 2000). The whole of pre-school services belong to the ministry of social affairs in some countries (generally, the Nordic countries), while public services in others are mainly offered to children from the age of three and are generally under the ministry of education (e.g. France). Given their different fields of competence, these policies are counted as different types of expenditure (social or education). In particular, pre-school programmes that serve as alternatives to childcare are not included in social expenditure data on childcare services. Therefore, for example, countries such as Belgium or Latvia investing 0.48 and 0.25 per cent of GDP respectively on childcare services in 2009 would be considered small spenders, in spite of the significant higher levels of resources on pre-school services ( 0.75 and 0.98 respectively). In order to correct for this, we include public expenditure on pre-primary education (ISCED 0$)^{x}$.

A second complication is that overall levels of public expenditure do not only depend on the public share of childcare costs, but also on the number of children attending childcare (and moreover the quality of services). In this sense, fluctuations in spending levels might not necessarily derive from changes in public financial support but rather from cross-national differences in the number of children below compulsory school age (Siegel 2007). Therefore, we 
weight the combined expenditure on childcare and pre-primary education by the proportion of children aged 0-5 years old ${ }^{\mathrm{xi}}$.

Public financial support index: (Social expenditure on childcare services as \% of GDP+ Expenditure on pre-primary schooling as \% of GDP)/ (Number of children 0-5/Total population)

The resulting ratio provides a crude measure of public financial support for formal childcare, which can be interpreted as the percentage of GDP invested in services for every one per cent of children below compulsory school age. The higher this index, the greater the public commitment to the delivery of extensive good quality childcare services. Figure 3 shows also in this case a great deal of variation across European countries. Our index ranges from 0.04 in Ireland to 0.55 in Demark. Calibration: resorting to previous empirical knowledge on our cases, we establish the first threshold (fully out) at 0.10 , a level commonly found in liberal states (UK, Switzerland) showing weak public investments and higher reliance on privately purchased childcare. The second threshold (fully in) is set at 0.40 , corresponding to a level of spending characteristic of Nordic social democracies (Denmark, Sweden) well known for their generous investments in high quality childcare services. Finally, the crossover point (.50) is set at 0.30 typical of countries identified in the literature has having ambivalent childcare policies (Germany, Finland) (Gornick and Meyers 2003; Morgan 2005; Randall 2000) xii $^{\text {ii }}$

[Figure 3]

\section{Results}

Table 4 shows countries' membership scores in the six ideal typical models. All the countries achieve membership in one of the configurations (table 5) with the exception of Belgium and the Netherlands $s^{\text {xiii }}$. There are differences across countries concerning the extent to which they reassemble one of these ideal type types with some showing low scores (e.g. 
Germany, Latvia, Portugal). The fact that these cases only partly fit into ideal types derives from the hybrid nature of their childcare policies, which are better described as a mix of more than one model.

The results of this analysis show that, despite a certain move toward the universal breadwinner model, childcare services remain embedded in traditional gender norms in the majority of European states. Austria, the Czech Republic, Germany, Greece, Latvia, Poland and Slovakia provide very limited alternatives to home-based childcare both in the form of service availability and public financial support. However, hours of childcare are with the exception of the Czech Republic full-time. This might be explained by the fact that employed women in these countries tend to be a highly selected group with similar working patterns to men and strong attachment to the labour market (Lewis et al. 2008). Accordingly, services appear to be tailored on the needs of those (few) mothers in employment. Adherence to the male breadwinner model is lowest in Germany and Latvia. In particular, concerns about declining fertility and low female employment in Germany have prompted governments to substantially reform childcare policies. New legislation in 2005 has considerably expanded investment in childcare services for children $0-2$, introducing the right to a childcare place for children older than 1 year (to be implemented in 2013). These changes represent a paradigmatic shift in German family policy, which break with traditional adherence to the principle of subsidiarity to the family and hostility to working mothers (Fleckenstein 2011). However, this new approach has not solved the many tensions and ambiguities surrounding childcare (Morgan 2013). Therefore, despite increasing investments in childcare services for children under three, the overall level of public resources and availability of childcare services remain too limited to establish a clear new model. Other contradictory measures were also introduced. For instance, a flat-rate monthly benefit ( $€ 150$ ) for parents who care for their children at home, and the fact that, although the period under which financial compensation for parental leave can be received was shortened (12 months), its duration can still last up to three years. The peculiarity of the German case also relates to the high degree of regional diversity within the country. Historically, childcare 
services were more developed in East Germany than in the West. In spite of a sharp decline in the region during the 1990s, West German coverage rates remain markedly lower to date (Hofäcker et al. 2011). In addition to such differences, the federal structure of the German state and the decentralised implementation of childcare policy, delegated at the level of municipalities and with a strong involvement of voluntary organisations, hinder the pace of reforms, allowing for the existence of different norms and systems at the sub-national level (Evers et al. 2005).

The caregiver parity model also promotes a traditional gender division of labour. Childcare policies strengthen women's role as mothers and the provision of care within the home in Bulgaria, Estonia, Finland, Hungary, Lithuania, Norway, Romania, Slovenia and Luxembourg. Accordingly, relatively well-paid and long parental leaves represent an important portion of available support, while childcare services remain less accessible. In contrast to the male breadwinner model, this model goes further in levelling opportunities for mothers across different socio-economic backgrounds to stay at home with their children. It often draws on the rhetoric of choice, understood as women's right to choose between a homemaker/mother role or paid employment (Mahon 2002). While public financial support for childcare services is also generally lacking, the level of public expenditure on formal childcare is among the highest in Europe in Finland, Norway and Hungary, reflecting a stronger emphasis on high quality services. Finland and Norway have already been singled out by previous research as the more traditional among the Nordic countries (Sainsbury 1996; Mahon 2002). Despite sharing a universalistic approach to childcare services, the volume of day-care differs substantially between these countries highlighting a different emphasis on female employment and nonparental childcare. Finland was the first of the Nordic states to introduce a cash-for-care scheme (1985) supporting parental care in the home, followed by Norway in 1998, while cash allowances are less relevant in Sweden and Denmark. These schemes have been particularly popular in Finland with more than half of children under-three cared through cash-for-care allowances in 2008, reflecting a public construction of childhood positively emphasising 
homecare. The political motive behind these measures was to ensure 'parental choice' and equality between parents who use day-care services and those who do not; moreover, arguments about cost containment were also at stake, parental care being cheaper than public childcare provision (Eydal and Rostgaard 2011). However, there is also a competing discourse about political fatherhood in Norway, as also shown by the recent extension of the fathers' quota to 12 weeks, the longest among Scandinavian countries. Nonetheless, the adoption of these allowances remains problematic since they are mainly used by women, lower income families and ethnic minorities, thus accentuating not only gender but also class and ethnic divides (Eydal and Rostgaard 2011).

We do not observe a general tendency in Europe toward the one-and-a-half breadwinner model, although this appears to be a particularly strong trend in the British context, where contentions about its diffusion have been particularly widespread (Daly 2011; Lewis 2001). Only in Switzerland, and the United Kingdom, do childcare policies actively promote a one-anda-half breadwinner (OHB) model. In these countries, children under-three are commonly cared for in day-care centres. However, these services are offered only for few hours (less than 20 hours a week), inducing parents (mothers) to resort to other informal arrangements (relatives, nannies) or choose (short) part-time jobs. The cost of childcare services falls prevalently on families as public financial contributions are very modest, or mainly provided through tax relief as in the case of the UK (Mahon 2002). The Netherlands comes close to this model but for the overall level of childcare support (S), which at 65 weeks of effective childcare coverage is slightly too high to achieve membership in this configuration. While we could characterize this country as a supported variant of the OHB model, we will see that it is better described as a hybrid between this and the universal caregiver model

This analysis also shows the existence of different variants within the universal breadwinner model. The unsupported breadwinner model (Cyprus, France, Ireland, Italy, Malta, Portugal, Spain) comes close to market-liberal type model. Therefore, full-time childcare services represent the largest part of available provisions, which remain nevertheless limited. 
Although these countries' policies do not openly promote separate gender roles for men and women, the scarceness of affordable childcare tends to perpetuate gender traditionalism owing to the dominance of cultural norms that place primary responsibility for childcare with mothers (Ciccia and Verloo 2012). Moreover, given the general reliance on private funding, this model does little to overcome class inequalities in access. Under such conditions, only high-income families and highly skilled women can afford to purchase good quality childcare, thus reinforcing polarisation among women along class divides (Saraceno 2011). France, Malta and Portugal have low memberships in this configuration. In France, in particular, there is an institutionalized divide between preschool and day-care (Morgan 2008). While preschool offers universal services for all children 3-6 years, services for under-three are relatively less developed, as is the level of public resource dedicated to childcare facilities. In spite of a long history of state support for working mothers, French family policy has been driven mainly by labour market considerations. Accordingly, in the context of increasing unemployment, the rate of increase of crèche places for under-three has slowed dramatically since the late nineties, while there have been substantial increases in public expenditure on cash benefits that either allow parents to hire an informal carer or to care for their children themselves (Lewis et al 2008). This development seem also to reflect a general approach to equality in France which is associated with the rejection of differences and of any special measure intended to address gender and other imbalances in the labour market (Crompton 2006).

The focus on maternal employment is accompanied by the provision of largely accessible, high quality and affordable childcare services only in Sweden, Denmark and Iceland, (supported universal breadwinner). Denmark is the country that goes further in promoting this model. The political goal of facilitating female employment has scored high on the political agenda gathering support from all political parties, and already in 1964 a law was passed giving municipalities responsibility for securing children a place in day care (Kremer 2007). As a result, Denmark has the highest proportion in Europe of children 0-2 years (68\%) cared for fulltime (35 average weekly hours) in day-care centres, even when compared to the other Nordic 
countries (30-40\%). This early and strong development of childcare services also reflects an emphasis on their pedagogical function. According to Kremer (2007), the ideal professional care promoted by the advocacy coalition of social pedagogues and women's movement has been crucial in securing extensive and high quality childcare in Denmark. Essential is the idea that childcare is more than a place where parents bring their children because they need to care for them, rather it provides a different kind of care that is fundamental to increase children's wellbeing, enhance their development, socialize them for school and for the labour market. Indeed, all welfare states implement to some degree the ideal of professional care for children aged 5-7, but Denmark is the only country where this ideal has been widely put in practice also for children 0-2. Accordingly, childcare services and pre-school are combined in a single system, and public investment in childcare services is very high, stressing both quality and universality of access. Nonetheless, the Danish gender equality project has been characterized as relatively 'narrow' as exemplified by the debates over the introduction and subsequent withdrawal of the father's quota in 2002, as an unduly interference of the state in private matters of families (Borchorst 2006). To date, Denmark remains the only Nordic country without a father's quota in parental leave. Gender equality concerns are mainly related to the equal participation of men and women in the labour market and less concerned with the equal division of care work in the family or parents' right to time for childcare (Eydal and Rostgaard 2011).

The more equalitarian universal caregiver model remains a gender utopia, and none of the countries analysed have childcare policies in place that aim at the recognition and redistribution of unpaid work. Three countries come close to it: the Netherlands, Denmark and Sweden. However, in all three cases the organisation of childcare differs in one crucial aspect from the universal caregiver ideal.

The Netherlands adhered for a long time to the male breadwinner model, and only since the 1990s, childcare services have been expanded as a way to endorse a 'combination scenario', involving a more balanced redistribution of paid and unpaid work (Bleijenbergh et al. 2006). This model was first launched in 1995 by a government commission, and its language was 
remarkably consonant with the universal caregiver model. Its point of departure was that, depending on the lifecycle phase, both men and women should be able to choose between a mix of long part-time work, part-time household production of care and part-time outsourcing of care (Plantenga 2002). Therefore, the institutional setting still favoured informal childcare in the home, yet also emphasised the need for a fundamental reconfiguration of working time and equal sharing of unpaid work between men and women. In this view, legislation was enacted to improve the quality of part-time jobs and ensure individuals' right to request part-time work. Although this strategy emphasises the reduction of working time, it does little to ensure that men and women equally share in working time reduction. Indeed, men's part-time employment (23.5\%) is by far the highest in Europe, but remains considerably below that of women (76.5\%) (Eurostat 2010). Parallel to these developments, government subsidies significantly expanded the supply of childcare services with childcare coverage rates for under-three increasing from around 6 to over 30 per cent between 1990 and 2008 (Morgan 2013). However, the childcare sector was also changed from a publicly-financed welfare sector into a demand-driven market sector in order to enhance efficiency. Since the 2005 Childcare Law, childcare has been provided by private organisations and financed through a mix of employers' contributions and incomerelated tax relief for families. It is particularly due to the peculiarities of this financing mechanism that the Netherlands falls short of the universal caregiver model in the organisation of childcare services. Given that the reconciliation of paid and care work is now incorporated in the social security system via labour costs and income taxes, public financial support for childcare services is comparatively low. Moreover, the amount of these subsidies has been progressively lowered since 2012, and new restrictions have been imposed regarding the access and maximum amount of hours of childcare (CCP, 2011).

While public responsibility for formal childcare is a long-standing principle in Denmark and Sweden, this also represents one of the shortcomings of this model. Given the primacy of the state in childcare, parents' right to time to care for their children receives limited recognition. Whereas children's right to spend their first year of life with their parents is generally a well- 
recognised principle, parents are thereafter strongly incentivised to place children in full-time childcare facilities. This is part of that wider social investment approach to childhood typical of Nordic countries (Lister 2009). Another principle of the Scandinavian welfare state also contributes to this outcome, its strong work ethic that identifies individuals' primary role as workers in the labour market. In this view, these countries provide too little recognition for parental care. For these reasons, despite having been singled out as those that go further in achieving the universal caregiver ideal, they are better characterised as universal breadwinner societies.

\section{Conclusions}

Childcare services for pre-school children exert a direct influence on the gender division of labour by offering parents the opportunity to outsource part of their childcare responsibilities, and thus to make more time for paid work. Although much has changed in the past decades regarding women's preferences and labour market participation, this has only marginally involved a shift in normative assumptions concerning childcare. Across many European countries, the organization of childcare services continues to assume a traditional division of labour. The male breadwinner and caregiver parity models remain the main normative models, and only a minority of countries have childcare services explicitly designed to support a universal breadwinner model. In the context of increasing maternal employment across much of the industrialised world, this puts particular strain on families to find their own private solutions for childcare. In this sense, changes in childcare policies have been contradictory and slower than changes in social realities (Daly 2011).

Universal breadwinner norms can shape different forms of childcare services according to the role of governments. In the supported universal breadwinner model, the state takes over responsibility for childcare by supplying universally accessible, high quality, publicly-financed services. This model can only be found in Iceland, Sweden and Denmark. The unsupported male breadwinner model provides limited childcare places leaving families largely to their own 
means in finding a solution for the care of children. While this variant is more common among European countries, it carries inherent threats. It perpetuates gender inequalities in the labour market because of the lack of affordable alternatives to maternal care, it exacerbates class divides by limiting access to high quality services for lower income families, and does not confront issues relating to quality of day-care services or the working conditions of people in care jobs (Gornick and Meyers 2009).

The universal caregiver model maintains its utopian character given that no European countries provides childcare services that offer mothers and fathers realistic opportunities to combine employment and care, and to adjust their working hours to allow time for the care of children. In this view, one of the defining characteristic of the universal caregiver model consists of policies that recognise parents' right to care for their children on their own, while at the same time offering different forms of assistance to deal with this responsibility; for instance, in the form of part-time day-care facilities. The Netherlands, Sweden and Denmark present traces of this model. Yet, the male breadwinner legacy of the Dutch childcare policy, and the employment focus of the Scandinavian welfare state prevent these countries from fully achieving such an ideal.

Finally, this paper demonstrates a number of advantages in the use of the configurational method for the analysis of care policies. First, such an approach directly confronts the complexity and multidimensionality of such policies by making sense of the ways in which these different aspects combine rather than averaging out differences. Second, FSITA deals explicitly with the hybrid nature of some policies and the existence of sub-types within certain models, namely that different policy configurations can uphold similar normative assumptions. Third, it clearly distinguishes between real, existing types and ideal types. This is especially manifest in relation to the Nordic countries. Although gender equality has been high on the political agenda, and although they might to a greater or lesser extent come closer to representing the 'real utopia' of gender equality (Gornick and Meyers 2009), they still fall short of representing gender nirvanas (Lister 2009). Our analysis shows internal diversity among Scandinavian countries, 
which have at best (Denmark, Sweden) enforced a particular version of gender equality very much based on notions of gender sameness and labour market participation, limiting parental choice with regard to time for care. By resorting to external conceptual standards such as Frasers' normative models, which do not depend on the characteristics of the cases investigated, FSITA goes beyond the real utopia approach by forcing us to consider the theoretical implications and empirical consequences of our normative ideals.

\section{AKNOWLEDGEMENTS}

We are grateful to Mieke Verloo, Marleen van der Haar and Cesar Guzman-Concha for the inspiration they gave us and for pointing us in the right direction. We also like to thank the participants of the ECPR Joint Sessions in Antwerp for constructive comments on an early version of this paper. Finally, our thanks are also due to Kimberly Morgan and two anonymous reviewers for their careful reading and valuable remarks 


\section{References}

Anttonen, Anneli. 2005. "Empowering Social Policy: The Role of the Social Care Services in Modern Welfare States." In Social Policy and Economic Development in the Nordic Countries, eds. 0. Kangas and J. Palme, 88-117. Basingstoke and New York: Palgrave Macmillan.

Bleijenbergh, Inge, Jet Bussemaker, and Jeanne de Bruijn. 2006. "Trading Well-Being for Economic Efficiency." Marriage \& Family Review 39 (3-4): 315-336.

Bambra, Claire. 2007. "Defamilisation and Welfare State Regimes: a Cluster Analysis." International Journal of Social Welfare 16 (4): 326-338.

Chau, Ruby C. M., and Sam W. K. Yu. 2012. "Defamilisation of Twenty-Two Countries: Its Implications for the Study of East Asian Welfare Regime." Social Policy and Society FirstView: 1-13.

Ciccia Rossella and Verloo Mieke.2012. "Parental Leave Regulations and the Persistence of the Male Breadwinner Model: Using Fuzzy Set Ideal Type Analysis to Assess Gender Equality in an Enlarged Europe." Journal of European Social Policy 22(5):507-528.

Centraal Planbureau (CCP). 2011. "Ex Post Analyse Effect Kinderopvangtoeslag op Arbeidsparticipatie", Centraal Planbureau: Den Haag.

Crompton, Rosemary, ed. 1999. Restructuring Gender Relations and Employment: The Decline of the Male Breadwinner. Oxford: Oxford University Press.

Crompton, Rosemary. 2006. Employment and the Family: The Reconfiguration of Work and Family Life in Contemporary Societies. Cambridge: Cambridge University Press.

Del Boca, Daniela., Silvia Pasqua, and Chiara Pronzato. 2009. "Motherhood and Market Work Decisions in Institutional Context: a European Perspective." Oxford Economic Papers 61 (1): 147-171. 
Daly, Mary. 2011. "What Adult Worker Model? A Critical Look at Recent Social Policy Reform in Europe from a Gender and Family Perspective." Social Politics: International Studies in Gender, State \& Society 18 (1): 1-23.

European Commission. 2004. "Development of a Methodology for the Collection of Harmonised Statistics on Childcare." Luxembourg: Office for Official Publications of the European Union.

Eurostat. 2010. Employment and Unemployment Statistics. Statistical Office of the European Communities.

Evers, Adalbert, Jane Lewis, e Birgit Riedel. 2005. "Developing Child-care Provision in England and Germany: Problems of Governance”. Journal of European Social Policy 15 (3): 195209.

Eydal, Guðný Björk, and Tine Rostgaard. 2011. “Gender Equality Revisited - Changes in Nordic Childcare Policies in the 2000s". Social Policy \& Administration 45 (2): 161-179.

Fleckenstein, Timo. 2011. "The Politics of Ideas in Welfare State Transformation: Christian Democracy and the Reform of Family Policy in Germany." Social Politics: International Studies in Gender, State \& Society 18 (4): 543-571.

Fraser, Nancy. 1994. “After the Family Wage: Gender Equity and the Welfare State.” Political Theory 22 (4): 591-618.

Gornick, Janet C., and Marcia K. Meyers. 2003. Families That Work: Policies for Reconciling Parenthood and Employment. New York: Russell Sage Foundation.

Gornick, Janet C., and Marcia K. Meyers, ed. 2009. Gender Equality: Transforming Family Divisions of Labor. New York: Verso.

Gregory, Abigail and Jan Windebank. 2000. Women's Work in Britain and France: Practice, Theory and Policy. Macmillan.

Hofäcker, Dirk, Rumiana Stoilova, and Jan R. Riebling. 2011. “The Gendered Division of Paid and Unpaid Work in Different Institutional Regimes: Comparing West Germany, East Germany and Bulgaria." European Sociological Review 29 (2): 192-209. 
Haas, Barbara, and Margit Hartel. 2010. “Towards the Universal Care Course Model." European Societies 12 (2) (May): 139-162. doi:10.1080/14616690902874705.

Hantrais, Linda. (2004), Family Policy Matters, Bristol: Policy Press.Hinrichs, Karl. 2000. "Elephants on the Move. Patterns of Public Pension Reform in OECD Countries." European Review 8 (03): 353-378.

Hobson, Barbara. 2011. “The Agency Gap in Work-Life Balance: Applying Sen’s Capabilities Framework Within European Contexts." Social Politics: International Studies in Gender, State \& Society 18 (2): 147-167.

Hudson, John, and Stefan Kuhner. 2010. "Beyond the Dependent Variable Problem: The Methodological Challenges of Capturing Productive and Protective Dimensions of Social Policy." Social Policy and Society 9 (02): 167-179.

—_- 2010. "Towards Productive Welfare? A Comparative Analysis of 23 OECD Countries." Journal of European Social Policy 19 (1): 34-46.

Jana Javornik. "Measuring state de-familialism: Contesting Post-Socialist Exceptionalism", forthcoming in Journal of European Social Policy.

Jenson, Jane. 1997. "Who Cares? Gender and Welfare Regimes." Social Politics: International Studies in Gender, State \& Society 4 (2): 182.

——_. 2009. "Lost in Translation: The Social Investment Perspective and Gender Equality." Social Politics: International Studies in Gender, State \& Society 16 (4): 446 -483.

Korpi, W. 2000. "Faces of Inequality: Gender, Class, and Patterns of Inequalities in Different Types of Welfare States." Social Politics: International Studies in Gender, State \& Society 7 (2): 127-191.

Korpi, Walter, Tommy Ferrarini, and Stefan Englund. 2013. “Women's Opportunities Under Different Family Policy Constellations: Gender, Class, and Inequality Tradeoffs in Western Countries Re-examined." Social Politics: International Studies in Gender, State \& Society 20 (1): 1-40. 
Kremer, Monique. 2007. How Welfare States Care: Culture, Gender and Citizenship in Europe. Amsterdam: Amsterdam University Press.

Kvist, Jon. 1999. "Welfare Reform in the Nordic Countries in the 1990s: Using Fuzzy-set Theory to Assess Conformity to Ideal Types." Journal of European Social Policy 9 (3): 231-252.

Leira, Arnlaug, and Chiara Saraceno. 2008. “Childhood: Changing Contexts.” Childhood: Changing Contexts. Bingley: Emerald: 1-24.

Leitner, Sigfrid. 2003. "Varieties of Familialism. The Caring Function of the Family in Comparative Perspective." European Societies 5 (4): 353-375.

Lewis, Jane. 1992. “Gender and the Development of Welfare Regimes.” Journal of European Social Policy 2 (3): 159-173.

_-_. 2001. "The Decline of the Male Breadwinner Model: Implications for Work and Care." Social Politics: International Studies in Gender, State \& Society 8 (2): 152-169.

Lewis, Jane, Mary Campbell, and Carmen Huerta. 2008. "Patterns of Paid and Unpaid Work in Western Europe: Gender, Commodification, Preferences and the Implications for Policy." Journal of European Social Policy 18 (1): 21.

Lewis, Jane, and Susanna Giullari. 2005. "The Adult Worker Model Family, Gender Equality and Care: The Search for New Policy Principles and the Possibilities and Problems of a Capabilities Approach." Economy and Society 34 (1): 76-104.

Lewis, Jane, Trudie Knijn, Claude Martin, and Ilona Ostner. 2008. "Patterns of Development in Work/Family Reconciliation Policies for Parents in France, Germany, the Netherlands, and the UK in the 2000s." Social Politics: International Studies in Gender, State \& Society 15 (3): 261-286.

Lister, Ruth. 2009. "A Nordic Nirvana? Gender, Citizenship, and Social Justice in the Nordic Welfare States." Social Politics: International Studies in Gender, State \& Society 16 (2): $242-278$.

Mahon, Rianne. 2002. "Child Care: Toward What Kind of 'Social Europe'?" Social Politics: International Studies in Gender, State \& Society 9 (3): 343-379. 
Morgan, Kimberly J. 2005. “The 'Production' of Child Care: How Labor Markets Shape Social Policy and Vice Versa", Social Politic: International Studies in Gender, State \& Society 12(2): 243-263.

Morgan, Kimberly J. 2008. "The Political Path to a Dual Earner/dual Carer Society: Pitfalls and Possibilities." Politics \& Society 36 (3): 403-420.

Morgan, Kimberly J. 2013. "Path Shifting of the Welfare State. Electoral Competition and the Expansion of Work-Family Policies in Western Europe." World Politics 65 (1): 73-115.

Myers, Robert G. 2000. "Financing Early Childhood Education and Care Services." International Journal of Educational Research 33 (1): 75-94.

O'Connor, Julia S. 1993. “Gender, Class and Citizenship in the Comparative Analysis of Welfare State Regimes: Theoretical and Methodological Issues." British Journal of Sociology 44(3): 501-518.

OECD. 2001. Early Childhood Education and Care. Paris: OECD.

Orloff, Ann Shola. 2006. "From Maternalism to 'Employment for All': State Policies to Promote Women's Employment Across The Affluent Democracies." In The State After StatismNew State Activities in the Age of Liberalization, ed. J. Levy, Cambridge, MA: Harvard University Press.

Pettit, Becky, and Jennifer Hook. 2005. "The Structure of Women's Employment in Comparative Perspective." Social Forces 84 (2): 779-801.

Pfau-Effinger, Birgit. 1998. "Gender cultures and the gender arrangement-a theoretical framework for crossnational gender research ". Innovations: The European Journal of Social Science Research 11(2): 147-166.

Pfau-Effinger, Birgit. 2005. "Welfare State Policies and the Development of Care Arrangements." European Societies 7 (2): 321-347.

Plantenga, Janneke. 2002. “Combining Work and Care in the Polder Model: An Assessment of the Dutch Part-time Strategy." Critical Social Policy 22 (1): 53-71. 
Plantenga, Janneke, Chantal Remery, Melissa Siegel, and Loredana Sementini. 2008. "Childcare Services in 25 European Union Member States: The Barcelona Targets Revisited." Comparative Social Research 25: 27-53.

Ragin, Charles C. 2000. Fuzzy-set Social Science, Chicago: University of Chicago Press.

Randall, Vicky. 2000. "Childcare Policy in the European States: Limits to Convergence." Journal of European Public Policy 7 (3): 346-368.

Rauch, Dietmar. 2007. "Is There Really a Scandinavian Social Service Model? A Comparison of Childcare and Elderlycare in Six European Countries." Acta Sociologica 50 (3): 249-269. Sainsbury, Diane. 1996. Gender, Equality, and Welfare States. Cambridge: Cambridge University Press.

Saraceno, Chiara. 2011. "Childcare Needs and Childcare Policies: A Multidimensional Issue." Current Sociology 59 (1): 78.

Saraceno, Chiara, and Wolfgang Keck. 2010. “Can We Identify Intergenerational Policy Regimes in Europe?" European Societies 12 (5): 675-696.

Saxonberg Steven. 2012. "From Defamilialization to Degenderization: Toward a New Welfare Typology." Social Policy and Administration 47(1):26-49.

Schneider Carsten Q., and Claudius Wagemann. 2012. Set-Theoretic Methods for the Social Sciences. A Guide to Qualitative Comparative Analysis. Cambridge: Cambridge University Press.

Siegel, Nico A. 2007. "When (only) Money Matters: The Pros and Cons of Expenditure Analysis." In Investigating Welfare State Change: The "Dependent Variable Problem" in Comparative Analysis, eds. J. Clasen and N. A. Siegel, 43-71. Cheltenham/Northampton: Edward Elgar. Szelewa, Dorota, and Michal P. Polakowski. 2008. "Who Cares? Changing Patterns of Childcare in Central and Eastern Europe." Journal of European Social Policy 18 (2): 115-131.

Tronto, Joan C. 1993. Moral Boundaries: a Political Argument for an Ethic of Care. London: Routledge. 
Vis, Barbara. 2007. "States of Welfare or States of Workfare? Welfare State Restructuring in 16 Capitalist Democracies, 19852002." Policy \& Politics 35 (1): 105-122. 


\section{Table and Figures}

Table 1: Childcare services ideal types

\begin{tabular}{llll}
\hline \multicolumn{1}{c}{ Ideal type } & $\begin{array}{c}\text { Childcare service } \\
\text { coverage }\end{array}$ & Formal childcare time & $\begin{array}{c}\text { Public financial } \\
\text { support }\end{array}$ \\
\hline Male breadwinner & Low & Full-time or part-time & Low \\
Caregiver parity & Low & Full time & Low or high \\
Universal breadwinner & High & Full-time & Low or high \\
Universal caregiver & High & Part-time & High \\
\hline
\end{tabular}

Table 2: Property space of childcare service ideal types*

\begin{tabular}{lcccc}
\hline \multicolumn{1}{c}{ Ideal type } & $\begin{array}{c}\text { Effective } \\
\text { childcare } \\
\text { coverage } \\
\text { (S) }\end{array}$ & $\begin{array}{c}\text { Childcare } \\
\text { mix }\end{array}$ & $\begin{array}{c}\text { Formal } \\
\text { childcare } \\
\text { time }\end{array}$ & $\begin{array}{c}\text { Public } \\
\text { financial } \\
\text { support } \\
\text { (C) }\end{array}$ \\
\hline Male breadwinner & $\sim \mathrm{S}$ & $\sim \mathrm{C}$ & $\sim \mathrm{H}$ or H & $\sim \mathrm{M}$ \\
One-and-a-half breadwinner & $\sim \mathrm{S}$ & $\mathrm{C}$ & $\sim \mathrm{H}$ & $\sim \mathrm{M}$ \\
Caregiver parity & $\mathrm{S}$ & $\sim \mathrm{C}$ & $\mathrm{H}$ & $\sim \mathrm{M}$ or M \\
Unsupported universal breadwinner & $\sim \mathrm{S}$ & $\mathrm{C}$ & $\mathrm{H}$ & $\sim \mathrm{M}$ \\
Supported universal breadwinner & $\mathrm{S}$ & $\mathrm{C}$ & $\mathrm{H}$ & $\mathrm{M}$ \\
Universal caregiver & $\mathrm{S}$ & $\mathrm{C}$ & $\sim \mathrm{H}$ & $\mathrm{M}$ \\
\hline
\end{tabular}

*Upper-case letters indicate membership in a set, while letters preceded by the symbol $\sim$ the absence of the set. 
Table 3: Dimensions and measures

\begin{tabular}{ll}
\hline \multicolumn{1}{c}{ Dimensions } & \multicolumn{1}{c}{ Measures } \\
\hline Childcare service coverage & $\begin{array}{l}\text { Effective childcare coverage rate (0-2 years) } \\
\text { Childcare mix index (0-2 years) }\end{array}$ \\
Formal childcare time & $\begin{array}{l}\text { Average number of weekly hours in formal care (0-2 years) } \\
\text { Public expenditure on family services and pre-primary } \\
\text { education as percentage of GDP adjusted for the proportion } \\
\text { of children 0-5 years }\end{array}$ \\
\hline
\end{tabular}

Figure 1: Effective childcare coverage and childcare mix in European countries (20052009)

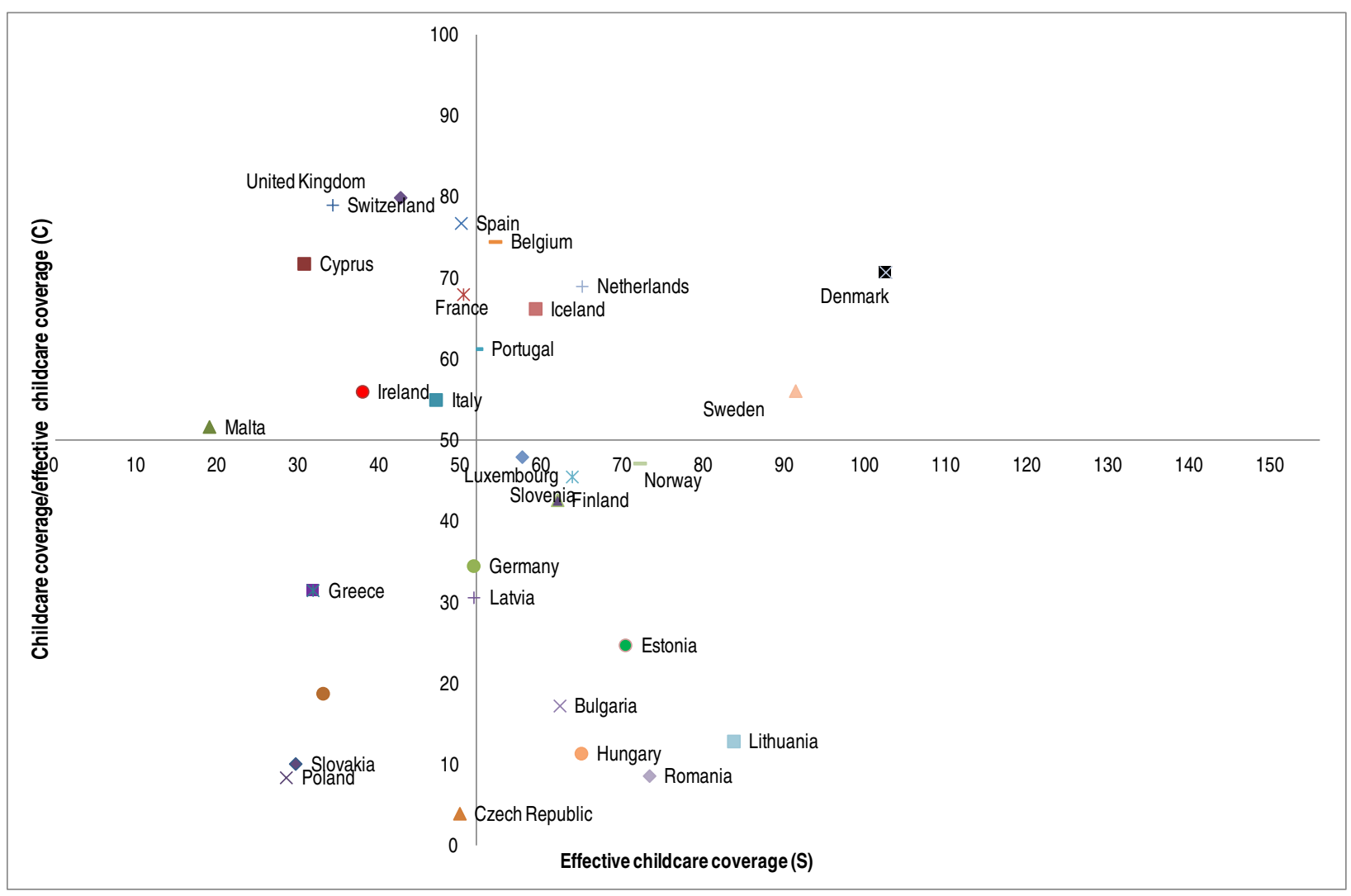


Figure 2: Average number of weekly hours of formal childcare (2005-2009)

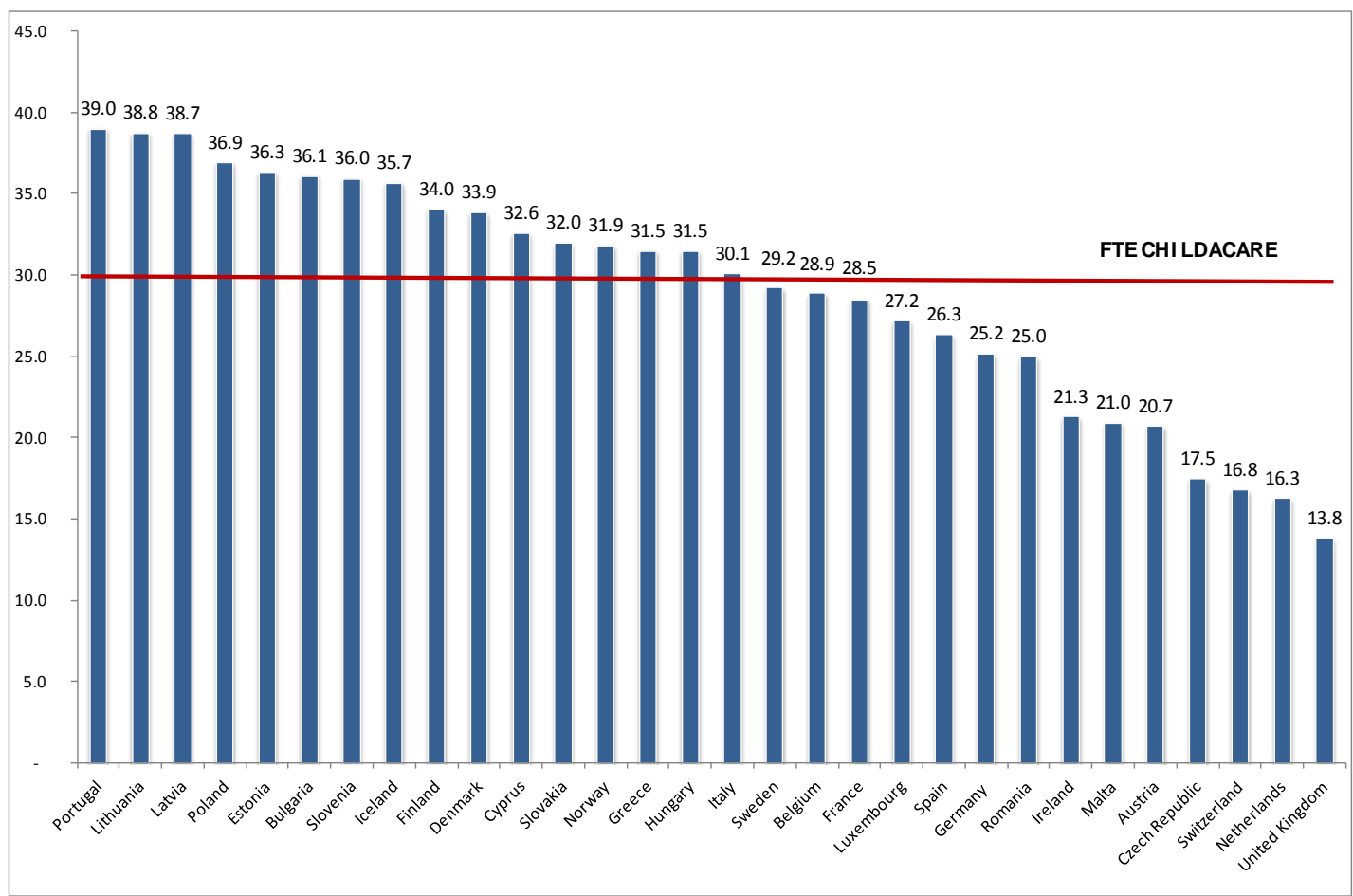

Figure 3: Public financial support index (2005-2009)

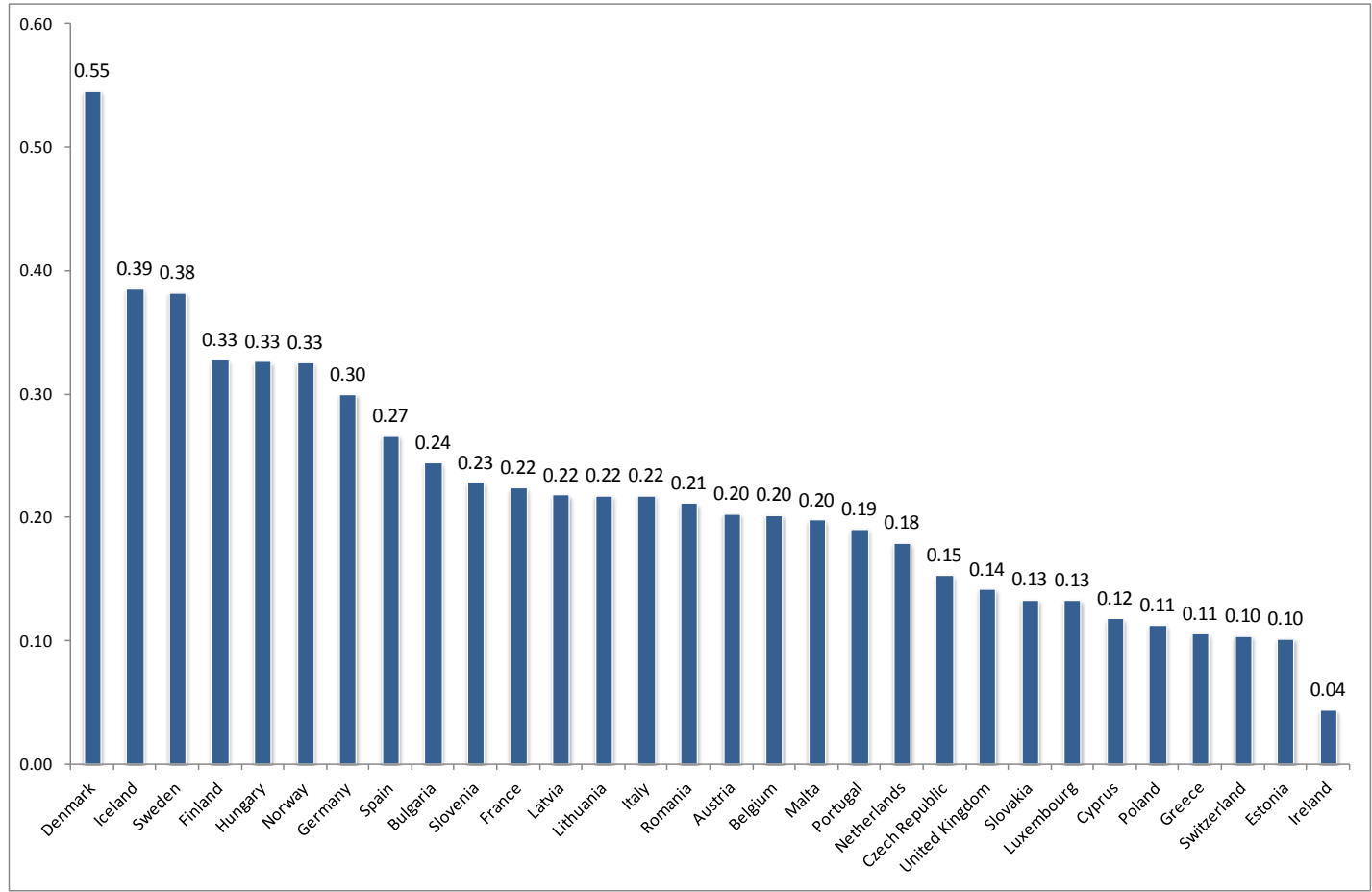

Table 4: Fuzzy membership scores of European childcare services* 


\begin{tabular}{|c|c|c|c|c|c|c|c|c|}
\hline \multirow{2}{*}{ Country } & \multicolumn{2}{|c|}{ Male breadwinner } & \multirow{2}{*}{$\begin{array}{l}\text { One-and-a- } \\
\text { half } \\
\text { breadwinner }\end{array}$} & \multicolumn{2}{|c|}{ Caregiver parity } & \multirow{2}{*}{\multicolumn{2}{|c|}{$\begin{array}{cc}\text { Unsupported } & \text { Supported } \\
\text { universal } & \text { universal } \\
\text { breadwinner } & \text { breadwinner }\end{array}$}} & \multirow{2}{*}{$\begin{array}{l}\text { Universal } \\
\text { caregiver }\end{array}$} \\
\hline & $(\sim \mathrm{H})$ & $(\mathrm{H})$ & & $(\sim \mathrm{M})$ & $(\mathrm{M})$ & & & \\
\hline Austria & 0.43 & 0.57 & 0.02 & 0.06 & 0.06 & 0.02 & 0.02 & 0.02 \\
\hline Belgium & 0.06 & 0.08 & 0.06 & 0.08 & 0.08 & 0.48 & 0.18 & 0.06 \\
\hline Bulgaria & 0.01 & 0.40 & 0.01 & 0.60 & 0.29 & 0.04 & 0.04 & 0.01 \\
\hline Cyprus & 0.02 & 0.10 & 0.02 & 0.05 & 0.05 & 0.90 & 0.05 & 0.02 \\
\hline Czech Republic & 0.57 & 0.35 & 0.01 & 0.35 & 0.10 & 0.01 & 0.01 & 0.01 \\
\hline Denmark & 0.00 & 0.00 & 0.00 & 0.00 & 0.11 & 0.00 & 0.89 & 0.01 \\
\hline Estonia & 0.01 & 0.32 & 0.01 & 0.68 & 0.05 & 0.07 & 0.05 & 0.01 \\
\hline Finland & 0.01 & 0.29 & 0.01 & 0.29 & 0.60 & 0.29 & 0.32 & 0.01 \\
\hline France & 0.06 & 0.14 & 0.06 & 0.14 & 0.14 & 0.56 & 0.23 & 0.06 \\
\hline Germany & 0.18 & 0.50 & 0.18 & 0.49 & 0.49 & 0.18 & 0.18 & 0.18 \\
\hline Greece & 0.03 & 0.86 & 0.03 & 0.05 & 0.05 & 0.14 & 0.05 & 0.03 \\
\hline Hungary & 0.03 & 0.29 & 0.02 & 0.29 & 0.63 & 0.02 & 0.02 & 0.02 \\
\hline Iceland & 0.01 & 0.06 & 0.01 & 0.06 & 0.17 & 0.06 & 0.57 & 0.01 \\
\hline Ireland & 0.35 & 0.35 & 0.43 & 0.12 & 0.02 & 0.57 & 0.02 & 0.02 \\
\hline Italy & 0.05 & 0.38 & 0.05 & 0.33 & 0.23 & 0.62 & 0.23 & 0.05 \\
\hline Latvia & 0.00 & 0.51 & 0.00 & 0.49 & 0.23 & 0.13 & 0.13 & 0.00 \\
\hline Lithuania & 0.00 & 0.21 & 0.00 & 0.77 & 0.23 & 0.02 & 0.02 & 0.00 \\
\hline Luxembourg & 0.11 & 0.44 & 0.11 & 0.55 & 0.07 & 0.44 & 0.07 & 0.07 \\
\hline Malta & 0.43 & 0.46 & 0.43 & 0.01 & 0.01 & 0.54 & 0.01 & 0.01 \\
\hline Netherlands & 0.13 & 0.13 & 0.37 & 0.13 & 0.13 & 0.23 & 0.14 & 0.14 \\
\hline Norway & 0.03 & 0.29 & 0.03 & 0.29 & 0.57 & 0.29 & 0.43 & 0.03 \\
\hline Poland & 0.01 & 0.95 & 0.01 & 0.03 & 0.03 & 0.02 & 0.02 & 0.01 \\
\hline Portugal & 0.00 & 0.24 & 0.00 & 0.24 & 0.16 & 0.50 & 0.16 & 0.00 \\
\hline Romania & 0.18 & 0.29 & 0.02 & 0.71 & 0.21 & 0.02 & 0.02 & 0.02 \\
\hline Slovakia & 0.06 & 0.93 & 0.02 & 0.04 & 0.04 & 0.02 & 0.02 & 0.02 \\
\hline Slovenia & 0.01 & 0.38 & 0.01 & 0.61 & 0.26 & 0.38 & 0.26 & 0.01 \\
\hline Spain & 0.06 & 0.06 & 0.14 & 0.06 & 0.06 & 0.57 & 0.39 & 0.14 \\
\hline Sweden & 0.06 & 0.08 & 0.06 & 0.08 & 0.35 & 0.08 & 0.65 & 0.06 \\
\hline Switzerland & 0.05 & 0.05 & 0.71 & 0.05 & 0.05 & 0.29 & 0.05 & 0.05 \\
\hline United Kingdom & 0.05 & 0.05 & 0.80 & 0.05 & 0.05 & 0.14 & 0.08 & 0.08 \\
\hline
\end{tabular}

*Scores in bold designate membership $(>0.50)$. Higher scores indicate a closer correspondence between a country's childcare policy and the ideal type.

Table 5: Countries membership in childcare service ideal types 


\begin{tabular}{ll}
\hline Model & Countries \\
\hline Male breadwinner & $\begin{array}{l}\text { Austria, Czech Republic, Germany, Greece, Latvia, Poland, } \\
\text { Slovakia }\end{array}$ \\
One-and-a-half breadwinner & Switzerland, United Kingdom \\
Caregiver parity & $\begin{array}{l}\text { Bulgaria, Estonia, Finland, Hungary, Lithuania, } \\
\text { Luxembourg, Romania, Slovenia, Norway }\end{array}$ \\
Supported Universal breadwinner & Iceland, Sweden, Denmark \\
Unsupported Universal breadwinner & Cyprus, France, Ireland, Italy, Malta, Portugal, Spain \\
Universal Caregiver & None \\
\hline
\end{tabular}

${ }^{i}$ In Fraser's (1994) terminology, we are unable to differentiate between caregiver parity and universal caregiver societies. A classical example of the two types of policies is a well-paid, relatively long maternity leave vs. a generous parental leave that also encourages fathers' to share equally this entitlement.

ii In comparison to other classification techniques such as cluster analysis, discriminant and latent class analysis based on measures of correlation/association and an optimization algorithm depending on the structure of existing data, FSITA follows a deductive approach. This method uses setmembership in order to define whether a case can be described by a concept or not, and the uncertainty expressed in fuzzy-sets stems from conceptual rather than empirical imprecision (Schneider and Wagemann 2012). This has important implications for the underlying measurement theory and the results of the analysis. Most importantly, researchers should avoid purely data driven calibration strategies since using parameters such as the mean or standard deviation implies that the classification of a case does not depend on the substantive meaning of the concept that one aims to capture, but on its relative value with regard to the other cases. This renders the classification very sensitive to the inclusion/exclusion of cases with extreme values, and also impedes the researcher from considering nonexisting types as may be the case when dealing with normative ideals. 
${ }^{\text {iii }}$ Childcare services analysed in this paper refer to education at pre-school or equivalent, education at compulsory education, childcare at centre-based services outside school hours, or childcare at day-centre organised/controlled by a public or private structure. Childcare by a professional childminder at the child's or child-minder's home is not included in this definition.

${ }^{\text {iv }}$ Cultural norms can also influence decisions about the use of childcare services (Pfau-Effinger, 1998; Kremer 1997). Although we cannot directly account for this, the effective coverage rate partially reflects these differences, since we can expect greater provisions and use of parental leave in countries where norms are more favourable to childcare in the home. Nevertheless, in some countries home care could be endorsed 'by default' by the lack of publicly provided alternatives to family care (Saraceno and Keck 2010).

${ }^{\vee}$ Full-time equivalents (FTE) are calculated as the duration of paid weeks of leave multiplied by the wage replacement rate.

vi Data on parental leave regulation refers to Ciccia and Verloo (2012), while data for childcare coverage is from EU SILC. We have used 5 years mean values (2005-2009) in order to reduce the effect of fluctuations due to labour market conditions and the risk of measurement errors.

vii It should be noted that a childcare mix index of $100 \%$ would contradict the principles of the universal caregiver model as outlined in section three, while it is compatible with both the supported and unsupported universal breadwinner models. Nevertheless, none of the countries analyzed shows values above $80 \%$ (figure 1 ).

viii Data refers to EU SILC (average 2005-2009).

ix It is very hard to obtain comparable national information on tax breaks for childcare services, given that they are not reported in social expenditure databases (ESSPROS). Further difficulties derive from large variation in tax breaks according to families' income, size, and children's age (Gornick and Meyers 2003). According to OECD estimates, tax breaks are especially relevant in Germany, Slovenia, France, Netherlands, Czech Republic, Belgium, representing between 0.6 and 1\% of GDP (OECD family database).

x Childcare services expenditure data is from the EUROSTAT ESSPROS database(2005-2009), while data on spending on pre-primary school refers to the EUROSTAT Education database (2005-2009). 
${ }^{x i}$ School entry age varies across Europe, yet children enter primary school at latest at the age of 6 years in most countries.

xii We have checked for the robustness of this intermediate threshold by using a lower cut-off point $(0.20)$. The use of this alternative value leads only to modest changes concerning four countries. Specifically, France, Germany, Italy, Latvia and Spain would not achieve membership in any of the ideal types.

xiii While the Netherlands configures a model $\left(\mathrm{S}^{*} \mathrm{C}^{*} \sim \mathrm{H}^{*} \sim \mathrm{M}\right)$ that is in between the OHB $\left(\sim \mathrm{S}^{*} \mathrm{C}^{*} \sim \mathrm{H}^{*} \sim \mathrm{M}\right)$ and the UC model $\left(\mathrm{S}^{*} \mathrm{C}^{*} \sim \mathrm{H}^{*} \mathrm{M}\right)$, the level of coverage and public financial assistance are slightly too high to achieve membership in either configurations. Belgium almost achieves membership (0.48) in the UUB $\left(\sim \mathrm{S}^{*} \mathrm{C}^{*} \mathrm{H}^{*} \sim \mathrm{M}\right)$, yet the effective childcare coverage (S) is also slightly too high (54 weeks) for this configuration. 